\title{
TO WHOM DOES THE CHARTER APPLY? SOME RECENT CASES ON SECTION 32
}

\author{
A. ANNE MCLELLAN $+\&$ BRUCE P. ELMAN $* \dagger$
}

\section{INTRODUCTION}

On April 17, 1982, the Canadian Charter of Rights and Freedoms' came into effect. In the ensuing three and a half years, over 2000 cases have been heard under the Charter. A great number of these cases have arisen in the context of a criminal investigation by the authorities followed by a prosecution by the state. Others have been concerned with statutory provisions or subordinate legislation which allegedly violate one or another of the fundamental freedoms. The vast majority of these cases pitted the individual against the state - either the federal government or the provincial government or their subordinates. Very few cases to date involve a Charter application made by one private citizen against another private citizen or concern. Therefore, the question, "does the Charter apply to private action?", has rarely arisen.

However, the question is an important one in terms of the Charter's overall scope. Section 32 of the Charter serves as a starting point for our discussion of this question. Section 32(1) of the Canadian Charter of Rights and Freedoms provides:

This Charter applies:

(a) to the Parliament and government of Canada in respect of all matters within the authority of Parliament including all matters related to the Yukon Territory and Northwest Territories; and

(b) to the legislature and government of each province in respect of all matters within the authority of the legislature of each province.

Two major issues have arisen in the context of s. 32 of the Charter:

1. To whom does the Charter apply? Does it apply only to the actions of "government" or does it apply to the actions of private citizens as well?

2. If the Charter applies only to "government action", what is to be included in that term?

On April 17, 1985, s. 15 - the so-called "equal protection or antidiscrimination" clause - came into ef fect. The question of to whom the Charter applies will arise much more frequently in equal protection litigation. This is not surprising when one considers that some potential plaintiffs, failing to obtain redress under provincial human rights legislation, may turn to the Charter for a remedy in matters having no governmental aspect. Consequently, the question takes on an added importance which it did not have in the first three years of the life of the Charter.

$\dagger$ Professors of the Faculty of Law, University of Alberta.

- McCalla Research Professor, 1985-86. Professor Elman wishes to acknowledge the generous support of the University of Alberta in providing assistance to pursue this research.

1. Constitution Act, 1982, as enacted by Canada Act 1982 (U.K.), c. 11 (hereinafter referred to as the Charter). 
The subject matter of this comment, then, is the problem of "To whom does the Charter apply?" The question of whether the Charter applies only to governmental activity or in addition, regulates wholly private action is the first one which we will examine. Then we will turn our attention to the issue of what activity may be included within the term "government". In the course of this comment we will examine three recent cases: $R$. v. Lerke, ${ }^{2} R$. v. H., ${ }^{3}$ and Blainey v. The Ontario Hockey Association and the Ontario Human Rights Commission. ${ }^{4}$ Let us begin with the question of whether the Charter can apply to purely private activity?

\section{THE CHARTER AND PRIVATE ACTION}

\section{A. ACADEMIC DEBATE}

From the outset, the question of whether the Charter applies to purely private activity has been a matter of some debate. Swinton, ${ }^{5}$ in an early commentary on the Charter, supports the position that the purpose of the Charter is to regulate the relationships of individuals with the government and not purely private relationships between individuals unconnected with government. In support of her position she argues that the nature of constitutional instruments, in general, and Charters of Rights, in particular, is that they define and regulate the scope of permissible government activity.

Further, Professor Swinton points out that the legislative history of s. 32(1) of the Charter supports the notion that the Charter does not bind the private actor. For example, s. 32(1) of the Charter, in each paragraph, closes with the words "in respect of all matters coming within the authority of' Parliament (in the case of s. 32(1)(a)) or the Legislature (s. 32(1)(b)). However, earlier drafts of the Charter in October 1980 and April 1981 contained the words "and to" in place of the phrase "in respect of". The words "and to" in the earlier versions could well have led to an interpretation of s. 32(1) which would have made the Charter applicable to private action. The replacement of the words "and to" with the phrase "in respect of" in the final version arguably indicates a desire upon the part of the framers of the Charter to limit the scope of the Charter to governmental action only. ${ }^{6}$

2. R. v. Lerke, unreported, 27 January 1986, J.D. of Edmonton (Alta. C.A.), affirming (1984) 13 C.C.C. (3d) 515 (Alta. Q.B.).

3. R. v. H., unreported, 24 October 1985, Edmonton Youth Court. Provincial Court Judge Russell.

4. Blainey v. The Ontario Hockey Association and the Ontario Human Rights Commission, (1985) 52 O.R. (2d) 225.

5. Swinton, "Application of the Canadian Charter of Rights and Freedoms" in Tarnopolsky and Beaudoin, Canadian Charter of Rights and Freedoms: Commentary, (1982) 41 at 44.

6. In this regard see Romanow, Whyte, and Leeson, Canada ... Notwithstanding, (1984) at 249. They suggest that the words "and to" used in the application section "turned the Charter not only into a constitutional document which restrained government, but a constitutional set of norms relating to the whole social activity within the country". This they say was "a radical transformation of the nature of the Charter." The words "in respect of" were substituted following the signing of the accord. They state: "... the wording of the application section was changed so that the Charter once again reached governmental action." 
This position was echoed in evidence given before the Joint Committee of the Senate and the House of Commons. F.J.E. Jordan, Senior Counsel for Public Law, Department of Justice, noted that the Charter did not "attempt to deal with private relationships".?

Swinton's position on this issue is supported by Hogg. ${ }^{8}$ In suggesting that the Charter does not apply to private action, Hogg cites two textual arguments. First, he points out that the text of s. $32(2)^{9}$ plainly assumes that $\mathrm{s} .15$ is effective as a result of the operation of $s .32(1)$. If this were not so, there would be no need for the inclusion of the phrase, "Notwithstanding subsection (1)", at the beginning of s-s. (2). Consequently, it is less likely that the sole purpose of s. 32(1) is to make it clear that the Charter applies to government as well as private action. Rather it seems more probable that s. 32(1) is present in the Charter to give force and effect to the guaranteed rights and to make it clear that the Charter is intended to bind government and not private actors with no relation to government. ${ }^{10}$

Secondly, the presence of s. 1 gives further evidence that the Charter was not intended to apply to private action. Section 1 provides that the rights are guaranteed subject to "such reasonable limits prescribed by law as can be demonstrably justified in a free and democratic society". The requirement that any derogation from a guaranteed right must be "prescribed by law" if it is to be held valid, means that private action in violation of a right could rarely be justified in accordance with s. 1 . However, there may well be examples of private discriminatory action which are justifiable."1

It is suggested that a third section of the Charter provides a textual context from which to view this issue. Section 24(2) provides the test for the exclusion of evidence obtained as a result of a Charter violation. It provides:

(a) Where, in proceedings under subsection (1), a court concludes that evidence was obtained in a manner that infringed or denied any rights or freedoms guaranteed by this Charter, the evidence shall be excluded if it is established that, having regard to all the circumstances, the admission of it in the proceedings would bring the administration of justice into disrepute. [Emphasis added.]

It has generally been held that all of the circumstances leading to the securing of the evidence must be examined to determine whether the "administration of justice would be brought into disrepute" by the admission of the evidence. It is difficult to see how "the administration of justice" could be brought into disrepute by actions of private citizens violating the constitutional rights of other private citizens. It appears to us unlikely that the framers of the Charter would have used such a provision as that contained in s. 24(2) if they intended that the Charter apply equally to private action as well as government action.

7. Proceedings of the Special Joint Committee of the Senate and of the House of Commons, Thirty-Second Parl., 1980-81, at 48:27 (January 29, 1981).

8. Hogg, Constitutional Law of Canada (2nd ed. 1985) at 674.

9. S. 32(2) provides: "Notwithstanding subsection (1), section 15 shall not have effect until three years after this section comes into force."

10. Supran. 8 at 675.

11. Id. at 676. Hogg cites two examples of private action in violation of Charter provisions which may be justifiable: "a denial of the right to speak at a private meeting (breach of $\mathrm{s}$. 2 ), or denial of private employment to a disabled person (breach of s. 15) ...". 
That is not to say that the opposite viewpoint does not have its proponents as well. Professor Gibson, for example, puts forward the view that the Charter should apply to the private sector as well as the public. ${ }^{12}$ His view appears to be premised upon three propositions. First, that the Charter itself was the product of compromise. As such there are those who did not want the Charter to apply to the private sector and, thus, refused to accept the previous drafts (i.e. the so-called "and to" draft referred to earlier). Similarly, others wanted the Charter to apply to private action and would not accept a provision which unequivocally limited the Charter's operation to government only. Consequently, Professor Gibson argues, the drafters of the Charter could have made it clear that the Charter applied exclusively to government, had they so desired, by simply adding the word "only" to s. 32(1). ${ }^{13}$ Therefore, Gibson concludes: ${ }^{14}$

\begin{abstract}
Ultimately, then, it is not a question of what was intended; competing intentions cancel each other out. The courts' task is to determine for themselves, on the basis of the language used, construed in the light of the kind of society to which Canadians aspire, the Charter's proper ambit.
\end{abstract}

Gibson's second proposition is that s. 32(1), making the Charter applicable to government, was added, not to exclude its application to private action, but to ensure its application to government as well. The basis for this argument is that legislation usually applies to private citizens but does not apply to the Crown unless the Crown is included expressly or by necessary implication. Therefore, s. 32(1) was added to the Charter out of an abundance of caution to ensure that courts would not later rule that the Charter did not apply to government. ${ }^{15}$

Gibson's third major proposition is that the Charter must be given a large and liberal interpretation commensurate with its status as a constitutional document and its remedial nature. Consequently, the courts should opt for a generous interpretation of those provisions which appear not to be restricted to government activity and allow the Charter to apply to private action where appropriate.

\title{
B. THE CASES:
}

The majority of cases decided to date support the notion that the Charter applies only to governmental activity. No decision of the Supreme Court of Canada or of provincial courts of appeal expressly addresses the issue. However, in Hunter v. Southam, Inc., ${ }^{16}$ Chief Justice

12. Gibson, "The Charter of Rights and the Private Sector", (1982-83) 12 Man. L.J. 213.

13. Id. at 213 .

14. Id. at 214. Support for this view may be found in the judgment of Mr. Justice Lamer in Reference Re Section 94(2) of the Motor Vehicle Act, R.S.B.C. 1979, c. 288 [1986] I W.W.R. 481 (S.C.C.)

15. Id. at 214-15. This appears to be a bit questionable. It is unlikely that the courts would have thought that ss. 8 (unreasonable search and seizure), 9 (arbitrary arrest), 10 (right to counsel), 11 (rights of those charged with an of fence), 12 (cruel and unusual treatment and punishment) and 14 (right to an interpreter in court proceedings), for example, did not apply to government.

16. (1985) 14 C.C.C. (3d) 97. 
Dickson, in deciding that ss. 10(1) and 10(3) of the Combines Investigation Act ${ }^{17}$ were inconsistent with $\mathrm{s} .8$ of the Charter (unreasonable search and seizure) and, therefore, invalid, made the following obiter comment: ${ }^{18}$

A constitution . . . is drafted with an eye to the future. Its function is to provide a continuing framework for the legitimate exercise of governmental power and, when joined by a Bill or Charter of Rights for the unremitting protection of individual rights and liberties.

Further on in the judgement, the Chief Justice stated:19

... in guaranteeing the right to be secure from unreasonable searches and seizures, section 8 acts as a limitation on whatever powers of search and seizure the federal or provincial governments already or otherwise possess.

Although these comments were not integral to the decision in Hunter v. Southam, they do demonstrate the Court's assumption that the purpose of a constitution is to regulate the relationship of the individual to government and not to interfere with purely private relationships.

In Re Klein and the Law Society of Upper Canada; Re Dvorak and The Law Society of Upper Canada, ${ }^{20}$ the Ontario Divisional Court was asked to rule on the constitutionality of certain rules and commentaries of the Law Society of Upper Canada which prohibited advertising fees and commenting to the press. In the course of argument, it was suggested to the Court that the Law Society was a private body. The Court rejected this suggestion and held that the Law Society of Upper Canada is "a statutory authority exercising its jurisdiction in the public interest" ${ }^{21}$ It can be assumed, we believe, that had the Court been of the opinion that the Charter applied to private action as well as governmental action, it would not have felt it necessary to establish a connection between the Law Society of Upper Canada and "government".

Other cases have more directly dealt with the issue. In Peg-Win Real Estate Ltd. and the Winnipeg Real Estate Board, ${ }^{22}$ it was held that the Charter did not apply to a matter solely between private individuals or corporations. ${ }^{23}$ The same result was reached in Chyz v. Appraisal Institute of Canada. ${ }^{24} \mathrm{Mr}$. Justice Wright held that the Appraisal Institute of Canada was a "private and voluntary association" which "should not be characterized as governmental in nature." ${ }^{25}$ His Lordship went on to state: ${ }^{26}$

As vital a balm as the Charter may be for the cure of society's ills and injustices it is not ... a panacea. Creative and liberal application of the Charter is to be encouraged but interpreters must remember that the words of section 32 are inherently restrictive, and that apparently by design.

17. R.S.C. 1970, c. C-23.

18. Supran. 16 at 105.

19. Id. at 106.

20. (1985) 16 D.L.R. (4th) 489 (Ont. Div. Ct.).

21. Id. at 528 .

22. (1985) 19 D.L.R. (4th) 438 (Man. Q.B.).

23. Id. at 416.

24. (1985) 36 Sask. R. 266 (Sask. Q.B.).

25. Id. at 274.

26. Id. 
In Larose v. The Queen, ${ }^{27}$ the court held that hospital personnel who took a sample of blood from the accused without his consent did not "fall within the purview of section 32." ${ }^{28}$ In two unreported Ontario District Court decisions, obiter comments that the Charter does not apply to private activity were made. ${ }^{29}$ Further, in the recent case of Blainey v. The Ontario Hockey Association and the Ontario Human Rights Commission, Mr. Justice Steele of the Ontario High Court held that "the Charter does not apply to private individuals", 30

The case of $R e$ Edmonton Journal and the Attorney General of Alberta ${ }^{31}$ raised the issue of the constitutionality of the in camera hearing provision (s. 12(1)) of the Juvenile Delinquents Act. ${ }^{32}$ In discussing the applicability of American cases, Mr. Justice Dea had occasion to compare the American and Canadian Constitutions. He stated:33

Put simply the American Constitution protects the rights of citizens against government interference whereas the Canadian Constitution protects the rights of citizens against any interference, be it government or private. Because of that difference in concept the contest in Canada may be as in the United States, i.e. between government and citizen or it may be quite different, i.e., between citizen and citizen. . . the freedoms so guaranteed not only limit government action which infringes or denies but also private action which has the same effect.

\section{R. V. LERKE ${ }^{34}$}

In this case, the accused, while in a tavern, was asked for proof of age and identification by a supervisor employed by the tavern. He was unable to comply with the request and was asked to leave the tavern. Sometime thereafter, the accused returned to the tavern. The manager of the

27. (1983) 25 M.V.R. 225 (Ont. D. Ct.).

28. Id. at 227. It appears that the judgment of Maranger D.C.J. is open to serious question. He states that:

There is no evidence whatever in this case to support a finding that the hospital personnel fall within the purview of $s .32$.

It is suggested that the proper inquiry is to determine whether hospitals and hospital boards come within the application of s. 32. If they are found to do so, then one must inquire into the nature of the relationship between the hospital board and the medical personnel, who allegedly violated the applicants Charter right(s). In this case, the blood samples were taken by a duly qualified lab technician after "a phone call from the lab." Such an individual clearly is an employee of the hospital board.

In most cases involving the taking of blood samples in the hospital setting, courts have assumed that the Charter applies. See, for example, Dyment v. The Queen (1984) 26 M.V.R. 225; R. v. DeCoste (1983) 128 A.P.R. 170; R. v. Pohoretsky (1985) 32 Man. R. (2d) 291 .

29. See R.v. Easterbrook, unreported, [1984] Ont. D. Crim. Conv. 5210-02 and R. v. Breckles, unreported, [1984] Ont. D. Crim. Conv. 6075-04.

30. Supran. 4 at 9 . This case will be discussed further, infra at n. 67.

31. (1983) 4 C.C.C. (3d) 59.

32. R.S.C. 1970 , c. J-3.

33. Supra n. 32 at 63 . The position taken by Mr. Justice Dea was probably the result of a comparison of the wording used in the American Bill of Rights with that used in the Charter. For example, the Ist Amendment of the American Bill of Rights begins "Congress shall make no law ..." and the 14th Amendment contains "No state shall make or enforce any law ... .". On the other hand s. 2 of the Charter begins "Everyone has the following fundamental freedoms ...", s. 8 "Everyone has the right . ..", and s. 15 "Every individual . . .". The wording of the Charter appears to be broader and arguably capable of the interpretation Mr. Justice Dea gives it.

34. Supran. 2. 
tavern, learning of this development, asked the accused to accompany him to his office. The accused did so. There, the manager, in the presence of two supervisors, asked the accused to empty his pant's pockets onto the table. The accused set his jacket to one side and began to empty his pockets. While so engaged, one of the supervisors searched the pockets of the jacket and found a packet of marijuana. The police were summoned and the accused was charged under the Liquor Control Act ${ }^{35}$ with entering a licensed premises after having been forbidden to do so and with possession of a narcotic contrary to the Narcotics Control Act. ${ }^{36}$ The charge pursuant to the Liquor Control Act was eventually withdrawn.

In the trial on the second charge, the Provincial Court Judge excluded the evidence of the marijuana, ruling that it has been obtained as a result of an unreasonable search and that its admission would bring the administration of justice into disrepute. In upholding the decision, $\mathrm{Mr}$. Justice Rowbotham held that the trial judge "did not err in applying the Charter to the circumstances of this case" ${ }^{37} \mathrm{His}$ Lordship held that the right to be secure against unreasonable search and seizure operates to protect individuals from other private citizens as well as governmental agencies. In so holding, his Lordship followed closely the reasoning of Mr. Justice Dea in the Edmonton Journal case and Professor Gibson in the article referred to earlier. Because of this finding, Mr. Justice Rowbotham did not have to consider "whether a private citizen making an arrest is exercising a governmental function". ${ }^{38}$

The Crown appealled to the Alberta Court of Appeal. Although the Court dismissed the appeal, they refused to decide the issue of whether the Charter applied to private activity. Chief Justice Laycraft stated: ${ }^{39}$

In my opinion the facts of this case do not raise the issue whether the Canadian Charter of Rights and Freedoms applies to the actions of one private citizen to another.

The Chief Justice went on to hold that the manager and his employees were exercising a governmental function. ${ }^{40}$ The Court held it would not interfere with the decision to exclude the evidence.

In conclusion, it is suggested that the better view is that the Charter applies only to government action. To hold otherwise would be to increase the scope of the Charter immeasureably. In cases involving arrests, detentions, searches and the like, to apply the Charter to purely private action would be tantamount to setting up an alternative tort system. In the area of private discrimination, an entirely new system of civil liability in competition with the dispute resolution mechanisms fostered by human rights legislation would result.

Arguably, human rights legislation provides a more efficient and less costly method by which an individual may seek redress for acts of private discrimination. The goal of human rights legislation, to settle disputes as

35. R.S.A. 1980 , c. L-17, s. $98(3)$.

36. R.S.C. 1970 , c. N-1, s. 3(1).

37. Supran. 2 at 520 (Q.B.).

38. Supran. 2 at 3 (C.A.).

39. Id. at 5 (C.A.).

40. Infra n. 56 and accompanying text. 
quickly as possible with as little acrimony and animosity as possible, will not be achievable when redress is sought through the courts pursuant to the Charter. It has been the authors' view, and continues to be our view, that: ${ }^{41}$

The very broad and general pronouncements of rights in the Charter is not the appropriate tool to resolve very specific allegations of discrimination which arise when one individual is accused of discriminating against another.

The same view was expressed by F.J.E. Jordan when addressing the Joint Committee of the Senate and of the House of Commons: ${ }^{42}$

\begin{abstract}
... the landlord refusing to rent his premises on one of the prohibited grounds of discrimination is amply covered by all the human rights codes which address themselves to the private areas of discrimination, and I can only say here that I think that the whole of the Charter is addressing itself to the protection for individuals against acts by the state, and 1 would be very worried if we ended up with a Charter that mixed into the domain of private infringement of liberties and freedoms. I think those are ones to be left to be dealt with by human rights codes.
\end{abstract}

\title{
D. FURTHER POSSIBILITIES:
}

This is not to say that the Charter can never have an impact on private activity. Examine the following hypothetical. A young person is denied employment with a private sector corporation because she is only seventeen years old. She will undoubtedly claim that she is being discriminated against on the basis of "age" contrary to s. 7(1) of The Individual's Rights Protection Act. ${ }^{43}$

In this case the employer would set up s. 38(a) of the same Act as a defence. Section 38(a) provides that age means 18 years of age and older.

The employee could then counter that s. 38(a) of The Individual's Rights Protection Act is inconsistent with $\mathrm{s.} 15$ of the Charter in that it does not provide for equal protection and equal benefit of the law and discriminates on the prohibited ground of age. If such an argument is successful and if s. 38(a) of the The Individual's Rights Protection Act cannot be justified pursuant to $s$. 1 of the Charter, then it will be of no force or effect. In this manner it is possible that the Charter will have a significant impact on an area of wholly private activity. ${ }^{44}$

A further hypothetical may be offered. An individual may be denied employment by a private sector employer based on a mental disability. If that individual wishes to seek some remedy for the alleged discrimination she will find The Individual's Rights Protection Act of no assistance. Mental disability is not one of the prohibited grounds listed in s. 7(1) of the Act. ${ }^{45}$ However, it is one of the grounds listed in s. 15 of the Charter

41. McLellan and Elman, "The Enforcement of the Canadian Charter of Rights and Freedoms: An Analysis of Section 24", (1983) 12 Alta. L. Rev. 205 at 233.

42. Supran. 7 at $48: 28$.

43. R.S.A. 1980 , c. I-2 as am. S.A. 1985, c. 15. Section 7(1) provides: “No employer or person acting on behalf of an employer shall (a) refuse to employ or refuse to continue to employ any person, or (b) discriminate against any person with regard to employment or any term or condition of employment, because of the race, religious beliefs, colour, sex, physical characteristics, marital status, age, ancestry or place of origin of that person or any other person."

44. Some provinces define "age" as being between 40 and 65 years. (See Human Rights Act, C.S.N.S., c. H-25 as am. These provisions would be open to challenge on the same basis. If such a challenge were to succeed, mandatory retirement would be ended.

45. Id. 
and is found in other provincial human rights legislation. ${ }^{46}$ It is at least arguable that mentally handicapped individuals in Alberta are denied equal protection and benefit of the law and consequently, s. 7(1) of The Individual's Rights Protection Act is inconsistent with the Charter in this regard. ${ }^{47}$

Thus the Charter may have a major influence on private activity through its effect on the law-making powers of the government. If the government legislates in regard to private activity in such a way as to permit or even encourage a private denial or infringement of rights, then the Charter may well have a significant, albeit indirect, effect on private action.

A further way in which the Charter may indirectly regulate private activity is seen in the American cases of Shelley v. Kraemer ${ }^{48}$ and New York Times v. Sullivan, ${ }^{49}$ where it was held that the courts and their processes could not be used in such a way as to violate constitutionally guaranteed rights. These cases both involve the assumption that the Charter applies to the courts, i.e. the term "government" in s. 32(1) includes the courts. Clearly several Charter sections imply that the courts are to be bound by the Charter. In particular, s. 11, dealing with the rights of the person charged with an offence, s. 12, concerning cruel and unusual treatment or punishment, s. 13, regarding self-incrimination, s. 14 , involving interpreters, and s. 19, regarding the language in court proceedings, indicate that the Charter applies to the courts. Further, a number of our courts are purely statutory creations and, therefore, appear to fall under s. 32(1). Finally, we normally view the courts and the judiciary as one of three institutions that fall under the common meaning of the word "government".

Shelley v. Kraemer provides an illustration of the possible effect of the Charter on private activity that would otherwise be "Charter-proof". In this case, the Supreme Court of the United States held that judicial enforcement of a restrictive covenant which prohibited a land owner from selling his land to anyone who was not white was a violation of the Equal Protection Clause of the Fourteenth Amendment. ${ }^{50}$ In New York Times v. Sullivan, the Supreme Court held, in a private defamation action, that the First Amendment guarantee of freedom of expression required that the common law of defamation in Alabama provide a defence of

46. See, for example, The Human Rights Act, C.C.S.M., c. H175, s. 6(1); Human Rights Act, S.B.C. 1984 , c. 22 , s. $8(1)$; and probably The Ontario Human Rights Code, S.O. 1982, c. 53, s. 4(1).

47. This raises two other problems worthy of note. First, what is the relationship of the various provincial human rights codes to the Charter? Are they statutes like any other provincial statutes whose provisions must not be inconsistent with those of the Charter? Do they have some special status which differentiates them from other statutes? The second issue involves what the appropriate remedy is in a case such as this hypothetical poses. If a court were to hold that s. 7(1) of The Individual's Rights Protection Act is inconsistent with the Charter, is the appropriate remedy to declare s. $7(1)$ invalid? Such a decision would remove the protection against discrimination in employment. On the other hand, does the court add the words "mental disability" to s. $7(1)$ to make the section conform to the Charter?

48. 334 U.S. 1 (1948).

49. 376 U.S. 254 (1963).

50. See also, Burrows v. Jackson 346 U.S. 249 (1953). 
"qualified privilege" to a newspaper when the newspaper was publishing material regarding a "public of ficial".

Therefore, although it appears likely the Charter will be found to apply to "government" action only, it may indirectly play an important role in regulating purely private action in the above-discussed manner.

\section{THE TERM “GOVERNMENT"}

\section{A. GENERAL DISCUSSION}

The preceding discussion, to a certain extent at least, begs the question. Assuming that the Charter does not apply to private action per se, the question remains as to what is included within the term "government action"? The use of the terms "Parliament" and "Legislature" in s. 32(1) clearly indicates that the Charter applies to the legislative activity of both levels of government. Any statute enacted by either level of government which is inconsistent with the Charter will be of no force or effect. This would apply to any persons or bodies exercising statutory authority. Hogg puts this proposition as follows: ${ }^{51}$

It follows that any body exercising statutory authority, for example, the Governor in
Council or Lieutenant Governor in Council, ministers, of ficials, municipalities, school
boards, universities, administrative tribunals and police officers, is also bound by the
Charter. Action taken under statutory authority is valid only if it is within the scope of
that authority. Since neither Parliament nor a Legislature can itself pass a law in breach
of the Charter, neither body can authorize action which would be in breach of the
Charter. Thus, the limitations on statutory authority which are imposed by the Charter
will flow down the chain of statutory authority and apply to regulations, by-laws,
orders, decisions and all other action (whether legislative, administrative or judicial)
which depends for its validity on statutory authority.

An example of this may be found in Re McCutcheon and the City of Toronto. ${ }^{52}$ In this case it was held that the Charter applied to municipal by-laws as the municipality was a subordinate body of the provincial government and legislature.

A further example may be found in the application of the Charter to provincial law societies. Upon this there appears to be almost universal agreement. Malartic Hygrade Gold Mines Ltd. v. The Queen in Right of Quebec, ${ }^{53}$ Black v. The Law Society of Alberta ${ }^{54}$ and Re Klein and the Law Society of Upper Canada; Re Dvorak and the Law Society of Upper Canada ${ }^{55}$ all concur that the respective provincial law societies fall within the scope of the Charter.

\section{B. R. V. LERKE ${ }^{56}$ (REPRISE)}

The Lerke case presents an interesting example in this regard. We have previously discussed this case and noted that Mr. Justice Rowbotham held that the Charter applied to private activity. In the Alberta Court of

51. Hogg, supra n. 8 at 671.

52. (1983) 147 D.L.R. (3d) 193 (Ont. H. Ct.).

53. (1982) 142 D.L.R. (3d) 512 (Que. S.C.).

54. (1983) 144 D.L.R. (3d) 439 (Alta. Q.B.) reversed on other grounds 8 D.L.R. (4th) 346 (Alta. C.A.).

55. Supran. 20.

56. Supran. 2. 
Appeal, the Crown appeal was dismissed although upon different grounds. Chief Justice Laycraft held that: ${ }^{57}$

the arrest of a citizen is a governmental function whether the person making the arrest is a peace officer or a private citizen.

There is ample support for this view. If it is correct, as Hogg contends, and as appears likely, that anybody exercising statutory authority falls under the rubric of "government", then a very cogent argument can be made that the tavern manager in the Lerke case can be considered as "government".

It will be remembered that Lerke was charged under s. 93(3) of the Liquor Control Act with entering a licensed premises after having been forbidden to do so. This section provides that anyone who re-enters a licensed premises after having been forbidden to do so is trespassing. ${ }^{58} \mathrm{~A}$ power of arrest is granted to the occupier of land and his servants pursuant to the Petty Trespass Act. ${ }^{59}$ It seems quite logical to argue that the tavern owner is exercising some degree of statutory authority over persons (and particularly trespassers) on his property. The legislature cannot itself pass a law in violation of the Charter and it cannot authorize action, even private actions, in breach of the Charter. Thus, on this theory, the Charter applies to the Lerke situation. Chief Justice Laycraft points out that the same reasoning would apply to an arrest pursuant to s. 449 of the Criminal Code. ${ }^{60}$

\section{R. V.H. ${ }^{61}$}

It is now settled that the Charter applies to actions taken by the Governor General in Council, the Lieutenant Governor in Council, the cabinet, ministers of the Crown, public servants, and the like. Cabinet decisions, whether based upon statute or prerogative power, come within the scope of the Charter and are reviewable by the courts. According to the Supreme Court of Canada, in Operation Dismantle v. The Queen, ${ }^{62}$ the executive branch of government, whether exercising statutory or prerogative powers, is bound to observe the dictates of the Constitution.

57. Id. at 5 (C.A.).

58. Section $98(3)$ provides:

A person who is in

(a) licensed premises, and does not immediately leave the licensed premises when requested to do so by the licensee or his employee, or

(b) premises for which a permit is issued, and does not immediately leave that place when requested to do so by the holder of the permit or his employee or agent.

is trespassing on the licensed premises or premises described in the permit, as the case may be.

59. R.S.A. 1980, c. P-6. Section 4 provides:

Any person found committing a trespass to which this Act applies may be apprehended without warrant by any peace officer, or by the owner or occupier of the land on which the trespass is committed, or the servant of, or any person authorized by the owner or occupier of the land, and may be forthwith taken before the nearest provincial judge or justice of peace to be dealt with according to law.

60. See also R. v. Easterbrook, supra n. 29, where Carnwath C.C.J. noted that the Charter did not apply to private action but applied to actions taken under statutory authority pursuant to $s .449$ of the Criminal Code.

61. Supran. 3.

62. (1985) 18 D.L.R. (4th) 481 (S.C.C.). 
An example of the application of the Charter to employees in the public sector can be seen in the recent case of $R$. v. $H$. In this case, Her Honour Judge Russell was asked to determine the admissibility of certain statements made by a pupil to a school principal and a teacher regarding the theft of money from a teacher's purse. The case revolved around whether a detention in a school principal's office was a detention within the meaning of $s .10$ of the Charter. As a prelude to answering the question, Provincial Court Judge Russell first addressed the question of whether the Charter applied to a school principal and teacher. In ultimately deciding that there had been a breach of s. 10 of the Charter and that the statements had to be excluded, Judge Russell stated the following in regard to the scope of $s .32$ of the Charter:63

\begin{abstract}
... because a number of sections are addressed to the conduct of public officials such as police officers, it is likely that the Charter would be interpreted as applying to those officials. Section 32 of the Charter prescribes the right of citizens to have their children receive primary and secondary education in French or English; if the Charter does not apply to school boards and their employees, this right could be meaningless. Section 93 of the B.N.A. Act gives the Legislature in each Province the exclusive power to make laws in relation to education; education is a matter within the authority of the legislature. [The Legislature] has chosen to govern the matter of education in the manner prescribed by the provisions of the School Act, R.S.A. 1980, S-3. That Act provides for the establishment of school boards. The Legislature has delegated certain authority to school boards including the authority to make rules regarding the suspension and expulsion of students: Section 155 . I am of the view that Parliament intended to extend the application of the Charter to include bodies such as school boards exercising a delegated legislative authority. I am satisfied that teachers and principals who are employees of school boards are governed by the provisions of the Charter.
\end{abstract}

Although it may come as a shock to principals and teachers that they are part of "government," Judge Russell's decision on this point would appear to be correct. It is equally certain that Crown corporations and statutory agencies will be included within the scope of the Charter.

\title{
D. "STATE ACTION" DOCTRINE
}

What of other bodies which are not agents of the Crown or statutory creations but which arguably are exercising public functions? Although the American "state action" doctrine has been described as subtle and elusive, ${ }^{64} \mathrm{a}$ brief examination of American jurisprudence may be helpful in understanding the different approaches the courts may take to this complicated issue. In this regard Gunther describes the two main tests employed to determine the scope of the "state action" doctrine:65

... most of the cases are preoccupied with the search for adequate elements of the

"state". That search for indicia of state action follow two distinguishable routes. One may be called the "nexus" approach; it seeks to identify sufficient points of contact between the private actor and the state to justify imposing constitutional restraints on the private actor or commanding state disentanglement. That approach is exemplified by Burton v. Wilmington Parking Authority . . . which states "that private conduct abridging individual rights does no violence to the Equal Protection Clause unless to some significant extent the State in any of its manifestations has been found to have become involved in it." That search for "significant state involvements" permeates most of the cases and raises numerous problems. The Burton approach assumes that a genuinely neutral state tolerance of private discrimination is permissible. But how much

63. Supran. 3 at 7.

64. See Re McCutcheon, supra n. 52; Reitmanv. Mulkey 387 U.S. 369 (1967).

65. Gunther, Constitutional Law - Cases and Materials (1980) at 986. 
active, affirmative engagement by the state is necessary under that approach? Is it enough that the state "authorize" the private discrimination? Can authorization be distinguished from mere tolerance, where the state has power to forbid private discrimination and does not exercise that power. What varieties of more active state involvement satisfy the state action requirement? Must the state be shown to approve discrimination? To encourage discrimination? Is it enough that the state confers some benefits on the private discriminator? Must there be special benefits, such as a grant of a monopoly? Is state regulation of the discriminator enough? State licensing? State leasing or sale or property? Is it enough that the stated judicial system enforces the private discriminator's wishes, as part of a general system of property and contract law? Questions such as these are characteristic of the "significant state involvements" approach.

The alternative to that "nexus" analysis is the "public function" approach. Instead of searching for formal contracts between the state and the private discriminator, it focuses on the nature of the activity the private discriminator engages in. Marsh $v$. Alabama, the company town case which follows, illustrates that approach. Basically, the "public function" analysis treats private enterprises whose "operation is essentially a public function" as sufficiently state-like to be treated as a state for the purposes of applying constitutional guarantees. This was one of the earliest, most amorphous, and potentially most far-reaching themes in the expansion of the state action concept, but the cases of the 1970's have curtailed it sharply.

\section{F. THE BLAINEYCASE66}

The recent case of Blainey v. The Ontario Hockey Association and the Ontario Human Rights Commission raises the difficult question of equal access to sports programs by women. The case involved an application by Justine Blainey, a twelve year old girl, to have s. 19(2) of the Ontario Human Rights Code ${ }^{67}$ declared contrary to ss. 15 and 28 of the Charter. In addition, Justine Blainey sought an interim order allowing her to play on the Metro Toronto Hockey League Team which had selected her as a member. She was one of fourteen of sixty-four players selected by the Olympics, an "A" team in the minor division of the Metro Toronto Hockey League, an affiliate of the Ontario League. Steele J. accepted that she was physically able to compete as a full member of that team, although all other members were boys. However, the facts indicate that to play on the team, a person must have a C.A.H.A. card. Regulation 250 of the Ontario Hockey Association restricts eligibility for membership to male persons. Therefore, Justine was not eligible for membership in the O.H.A. A team or club which allows a person to play without a card may be suspended from playing with other teams under the supervision of C.A.H.A. Mr. Justice Steele found that the Ontario Hockey Association and the Canadian Amateur Hockey Association were private bodies to which the Charter had no application.

There are some questions that might be asked however. What function does the C.A.H.A. and the O.H.A. serve vis-à-vis young persons who wish to play hockey in Canada? It appears that the C.A.H.A., through its control of minor hockey in Canada, can determine which individuals will be capable of playing on which teams and at which levels. Further it controls many, if not all, of the amateur hockey tournaments in the country and may determine which teams can be selected to participate in these tournaments. It is no doubt extremely important for youngsters who wish to play hockey in Canada (let alone pursue a career in hockey)

66. Supran. 4.

67. S.O. 1981, c. 53 . 
to be members of the C.A.H.A. Further, it is probably equally important for teams to remain in the good graces of the C.A.H.A. The nature and extent of the control exercised by the C.A.H.A. and its provincial counterparts over minor hockey is unlike those functions normally exercised by volunteer organizations. It appears that the C.A.H.A. extensively regulates the involvement of Canadian children in minor hockey programs. They apparently control the admission into the program and progress through its various developmental stages. They affect the ability of children to participate in the program and, possibly, even pursue a career in the sport. An argument can be made that the C.A.H.A. and the O.H.A. exercise a "public function" in their activity which makes them appear to be like "government" for the purposes of applying the Charter to their allegedly discriminatory activities. ${ }^{68}$

It must also be noted that the C.A.H.A. receives a significant portion of its funding from various government agencies. This funding comes primarily from the federal government and the municipalities. In regard to this Mr. Justice Steele stated:69

\begin{abstract}
It was also suggested that, because the C.A.H.A. and the O.H.A. receive substantial grants from the federal government under the Fitness and Amateur Sport Act, R.S.C. 1970 , c. F-25, and from various municipalities, they are exercising a government function. The Fitness and Amateur Sport Act does not authorize the government to provide athletic services. It merely authorizes grants to assist the Association. This does not make the C.A.H.A. or the O.H.A. governmental agencies. To hold otherwise would mean that all industries, charities and other organizations that receive government grants are performing government functions and are subject to the Charter. This is not the intent of s. 32 of the Charter.
\end{abstract}

This, however, misses the point. One of the most important functions of government is to expend funds to support and advance its policies. The question must be raised as to whether it is ever appropriate for government to provide public funds to organizations which in some, or all, aspects of their activities allegedly discriminate. It would appear to us that when the public nature of the C.A.H.A. is coupled with its nexus to government through public funding, a very good argument can be made that the C.A.H.A. is part of "government" for the purposes of the Charter.

\title{
IV. COMMENT
}

Section 32 of the Canadian Charter of Rights and Freedoms seems simple enough. However, the cases of $R$. v. Lerke, ${ }^{70} R$. v. H. ${ }^{71}$ and Blainey v. The Ontario Hockey Association and the Ontario Human Rights Commission 72 provide an interesting glimpse into its mysteries. In $R$. v. $H$., the provincial court judge held that principals and teachers in the public school system are included within the scope of the term "government". Although some teachers may find it disconcerting to be viewed as

68. See Marsh v. Alabama 326 U.S. 501 (1946) where the United States Supreme Court held that the right to distribute religious literature within the confines of a company-owned town was constitutionally protected because the town, although privately owned, exercised a "public function" vis-à-vis its citizens and visitors.

69. Supran. 4 at 230-231.

70. Supran. 2.

71. Supran. 3.

72. Supran. 4. 
part of the state, this case places new obligations upon teachers vis-à-vis their students which they arguably did not previously have. The case seems to rest upon a chain of delegation leading from the provincial legislature to the public school board to the teacher employee of the board. If the Charter applies to school boards, it seems likely that employees of the boards will also be bound by the provisions of the Charter. In this regard the result in $R$. v. $H$. seems to be correct.

In $R$. v. Lerke the issue of whether the Charter applied to private action seemed to be squarely before the Alberta Court of Appeal. However, the Court of Appeal declined to address the issue, holding that a manager of a tavern, when exercising his statutory authority to arrest, pursuant to the Petty Trespass Act, was considered to be a part of "government". This also appears to be a reasonable decision. If private individuals are going to exercise statutory authority, they must follow the dictates of the Constitution when they do so.

In the Blainey case, the issue was where to draw the line between private and govenmental functions. Serious issues are raised about the "public" nature of the functions exercised by organizations such as the O.H.A. and the C.A.H.A. Furthermore, the direct and indirect financial support provided to these organizations by the government raises questions regarding the nexus between them and government.

\section{CONCLUSION}

Although we are of the opinion that the Charter does not and should not apply to purely private action, the scope of the term government, as defined by the courts, will be extremely important to the effectiveness of the Charter. It may be inappropriate, if not impossible, to provide an allencompassing definition of the term "government" in the abstract. The courts probably will approach the question on a case by case basis. To lay down hard and fast rules concerning s. 32, at this stage of the development of Charter jurisprudence, may be undesirable.

It can be ascertained from the foregoing discussion that, even if the Charter does not apply to the "private sector", there may be a great number of instances where it will affect what would otherwise be seen as wholly private activity. It may do so by requiring that provincial legislation, which regulates private activity, be struck down. Further, the Charter may affect the private sector, through an expansive definition of government. More probably, however, the Charter will have its greatest impact on private activity through moral suasion. 